Article

\title{
New Media Components and Fertilization to Accelerate the Growth of Citrus Rootstocks Grown in a Greenhouse
}

\author{
Sandra C. Arce and Dania Rivera * \\ Agro-Environmental Sciences Department, University of Puerto Rico-Mayagüez, P.O. Box 9000, Mayagüez, \\ PR 00681, USA; agro.sarce@gmail.com \\ * Correspondence: dania.rivera@upr.edu; Tel.: +1-787-859-3075
}

Received: 10 May 2018; Accepted: 4 June 2018; Published: 10 June 2018

\begin{abstract}
In Puerto Rico, oranges made up \$6,452,000 of the agricultural gross income for 2014-2015. Today, citrus greening (CG) is the most aggressive disease affecting the citrus industry in the whole world. This disease causes dieback of the plant, among other symptoms, which is resulting in the reduction of citrus trees in the field across the world. Currently, it is recommended to grow citrus rootstocks in nurseries to produce disease-free trees. The objective of this investigation was to evaluate (before and after grafting) the effect of different substrate mixes and quantities of fertilizers on the rootstocks Carrizo citrange and Swingle citrumelo in order to accelerate their development inside of a protected structure. The treatments were: Promix + sand (control) (1:1), Promix + sand + coco peat (1:1:1), Promix + sand + coffee compost (1:1:1) and Promix + sand + rice husk (1:1:1). Two 18-6-2 fertilizer treatments were also evaluated: $5.6 \mathrm{~g}$ and $8.5 \mathrm{~g}$. The substrate that contained $33 \%$ rice husks negatively influenced every parameter evaluated for both rootstocks. Carrizo presented better development on the coffee compost mix, while Swingle did not exhibit significant differences among any substrates, except on rice husk, for most of the parameters. "Rhode Red Valencia" presented better results for dry weight when grafted on Carrizo with the coffee substrate. The rice husk substrate is not recommended for the citrus tree production at the nursery level.
\end{abstract}

Keywords: Carrizo citrange; Swingle citrumelo; citrus greening; protected greenhouse; substrates

\section{Introduction}

In 2014-2015, among fruit, oranges were in third place in the gross income of Puerto Rico, contributing $\$ 6,452,000$ to the island's economy [1]. However, in the last few years, the production of citrus on the island has decreased remarkably. Citrus greening (CG) disease, caused by the bacteria Candidatus Liberibacter asiaticus (CLas), has become the principal cause of the worldwide reduction of citrus production [2]. Citrus trees infected with CG present acidic fruits, asymmetric foliar chlorosis, diminished life cycle and, eventually, the tree presents dieback [2,3]. In Puerto Rico, the citrus psyllid Diaphorina citri (vector of CG) was first detected in 2001, while the presence of the bacteria, thus the presence of CG, was first detected in 2009 [4,5]. Since then, there has been a reduction in citrus production, from 3500 tons in 2014 to 1080 tons in 2016 [6]. Biological control, harsh pesticide treatments and thermotherapy are some of the controls that are being implemented to control either the vector or disease of CG [7-9]. Another recommendation to maintain a stable citrus production is the elimination of advanced diseased trees, applications of intensive fertilizer practices, production of citrus trees inside protected structures and on-site planting of disease-free citrus trees [10].

Grafted trees produced inside protected structures have the advantage of producing strong, disease-free trees, which can help fight the loss of citrus trees in the field caused by CG disease [11]. 
The production of healthy citrus liners in containers inside of a protected nursery facilitates the development of a vigorous root system that results in a stronger/healthier plant [12]. Substrates, fertilizers and hormones can help accelerate the growth of citrus rootstocks, and the combination of rootstock/scion can help shorten the time until transplanting to the field and provide some measure of resistance to diseases [13].

Rootstocks not only provide a supportive root system, they also provide a better absorption of nutrients and water. They can also contribute characteristics to the resulting tree, such as tolerance to low temperature, high salinity, flooding and varying soil $\mathrm{pH}$, and resistance/tolerance to nematodes and diseases [14]. Of the multiple citrus rootstocks used in the industry, we evaluated Carrizo citrange and Swingle citrumelo. Carrizo citrange (Citrus sinensis x Poncirus trifoliata) has shown resistance to damage by Phytophthora and citrus tristeza virus (CTV), an elevated resistance to the Tylenchulus semipenetrans nematode and some resistance to the CG disease [15]. Swingle citrumelo (Citrus paradise Macf. x Poncirus trifoliata) has presented good adaptation to sandy soils; a high germination percentage; an extensive radicular system; and moderate tolerance to salinity, boron toxicity, and CTV [16,17]. Rootstocks help solve problems with soil, climate, pests and diseases, and can also influence the quality of production of the chosen scion [18]. It is important to choose a good rootstock/scion combination [18]. For the scion, we evaluated the variety Rhode Red Valencia. This orange presents intense color, low acidity, low vitamin C and $400 \%$ more antioxidants in comparison to other oranges [19].

Not only the combination of rootstock/scion can reduce the time of development of the tree-the substrate can also affect the time of development [20]. With the ideal substrate mix for a crop, one can therefore provide the optimal environment for the growth of an extensive root system [21,22]. The citrus plant root system is limited, which results in a poor capacity for nutrient absorption [23]. Therefore, a way of aiding the necessities of the citrus plant is through the components of the substrate mix and the fertilizer [23].

Many substrate components are used at the nursery level and, for this research, a few of them were chosen for evaluation: peat moss, river sand, coco peat, coffee compost and rice husk. Peat moss is the result of decomposition of vegetable matter in an anaerobic environment; it usually exhibits a $\mathrm{pH}$ of $5.3-6.5$ and more than $80 \%$ organic matter [24,25]. River sand, or any sand, is frequently used to provide weight to the pot. Usually, it exhibits a neutral $\mathrm{pH}$ and a low capacity for cationic exchange [22,26]. Coco peat is shredded coconut husk. Some characteristics of this substrate are: a $\mathrm{pH}$ that ranges from 5.3-6.3, high electric conductivity and water retention of 700-1100\% [24,27]. Compost, in general, is the transformation of organic matter that results in a new material that can favor oxygenation of the soil and substrate and promote higher root growth [28]. Rice husk is the product of processing rice, and as a substrate it can provide higher air porosity $[29,30]$. In Puerto Rico, little to no research has been done with these materials.

\section{Materials and Methods}

The experiment was conducted inside a nursery at the Agricultural Experiment Station (AES) in Corozal, Puerto Rico. The nursery was protected with a mesh $(0.24 \mathrm{~mm} \times 0.75 \mathrm{~mm}$, Empresas San Pablo, Lares, PR, USA) to avoid entrance of the psyllid and large insects. The biosecurity protocol to enter the nursery consisted of using a lab coat and hair net and disinfection of footwear with sanitizing solution (sodium hypochlorite $(\mathrm{NaClO})$ at $10 \%$ ) to avoid the entrance of pathogens and insects. The first door of the nursery had an air curtain (48", Mars Airs Doors, Gardena, CA, USA), which automatically started when the door was open. When the first door closed, the second door could be opened to enter the nursery.

Two citrus rootstocks were evaluated: Carrizo citrange and Swingle citrumelo. The seeds were obtained from the rootstock collection at AES, Corozal. The seed were germinated in a commercial mix (Pro-Mix BX with mycorrhizae) on 72-hole germination trays. After 3 months, on 14 April 2015, the seedlings were transplanted to $10.2 \times 30.5 \mathrm{~cm}(4 \times 12 \mathrm{inch})$ square pots $(\mathrm{CP} 412 \mathrm{CH}$, Stuewe \& 
Sons. Inc., 31933 Rolland Drive, Tanget, OR, USA) containing the different substrate and fertilizer treatments. All the substrates were sterilized with water vapor $\left(100{ }^{\circ} \mathrm{C}\right)$ for $4 \mathrm{~h}$ at AES in Adjuntas. The commercial mix used was Pro-Mix Sunshine Mix \#4. This product contained Canadian peat moss, dolomitic lime, coarse grade perlite, gypsum and Sun Gro's long-lasting wetting agent. The coco peat used was a commercial block made of coconut husk, compacted and imported by Empresas San Pablo, Lares, PR. The coffee compost was obtained from the AES in Adjuntas and had 4.89\% nitrogen, $0.46 \%$ phosphorus, $3.33 \mathrm{mS} / \mathrm{cm}$ electric conductivity (EC) and a $\mathrm{pH}$ ranging from 6.72 to 6.84 [31]. The rice husk was obtained from a rice planting in the Department of Agriculture. The sand used was river sand obtained from Corozal, Puerto Rico. The fertilizer quantity per treatment was calculated from the low (F1-5.6 g) and high (F2-8.5 g) recommendations of the product Caliber Cote 18-6-12 (Homogeneous Trace Pack, Helena Chemical Company, Collierville, TN, USA). There were two applications of fertilizers: at the transplant date or start of the experiment and 3 months later. The experiment was conducted from April 2015 to February 2016. The combinations of control media, substrates and the fertilizer quantities are described in Table 1.

Table 1. Treatment abbreviations with substrate combination and fertilizer amount applied.

\begin{tabular}{cccc}
\hline Treatments & Substrate Mix & Ratio per Volume & Fertilizer \\
\hline Control + F1 & Commercial mix + river sand & $1: 1$ & $5.6 \mathrm{~g}$ \\
Control + F2 & Commercial mix + river sand & $1: 1$ & $8.5 \mathrm{~g}$ \\
Coco peat + F1 & Commercial mix + river sand + coco peat & $1: 1: 1$ & $5.6 \mathrm{~g}$ \\
Coco peat + F2 & Commercial mix + river sand + coco peat & $1: 1: 1$ & $8.5 \mathrm{~g}$ \\
Compost + F1 & Commercial mix + river sand + coffee compost & $1: 1: 1$ & $5.6 \mathrm{~g}$ \\
Compost + F2 & Commercial mix + river sand + coffee compost & $1: 1: 1$ & $8.5 \mathrm{~g}$ \\
Rice + F1 & Commercial mix + river sand + rice husk & $1: 1: 1$ & $5.6 \mathrm{~g}$ \\
Rice + F2 & Commercial mix + river sand + rice husk & $1: 1: 1$ & $8.5 \mathrm{~g}$ \\
\hline
\end{tabular}

\subsection{Evaluation of Rootstock}

\subsubsection{Height and Diameter}

The height $(\mathrm{cm})$ of each plant was taken from the top of the substrate to the petiole of the newest leaf every 2 weeks for 6 months. Tree diameter was taken at $5 \mathrm{~cm}$ from the substrate with a caliper (digital caliper, ABSolute AOS Digimatic, Mitutoyo Corp., Takatsu-ku, Japan) every 2 weeks for 6 months.

\subsubsection{Chlorophyll}

Chlorophyll of the rootstock leaves was measured with a chlorophyll meter (Field Scout, Chlorophyll Meter with Data Logger, Spectrum Technologies) every 2 weeks. The leaves sampled were the newest, fully-opened leaves. On each plant, three measurements of the same leaf were taken, and an average was calculated.

\subsection{Evaluation of Rootstocks Grafted with "Rhode Red Valencia"}

\subsubsection{Height}

After 6 months, the rootstocks were grafted with "Rhode Red Valencia" (Citrus sinensis L. Osbeck) Vegetative material of "Rhode Red Valencia" was obtained from trees kept inside protected structures at AES at Isabela, Puerto Rico. The height of the developing scion was measured from the grafting site to the petiole of the newest leaf.

\subsubsection{Chlorophyll}

The same instruments and procedure as explained before were used with the scion for chlorophyll. 


\subsection{3. $\mathrm{pH}$ and $\mathrm{EC}$}

Samples of all the substrate treatments were sent to the Central Analytical Laboratory of the University of Puerto Rico at the beginning of the experiment for chemical properties testing. The $\mathrm{pH}$ and electric conductivity (EC) were measured by the pour-through method [32] ( $\mathrm{pH} / \mathrm{EC} / \mathrm{TDS}$ Meter, Milwaukee, MW 802) every 2 weeks, from planting until the end of the experiment.

\subsubsection{Dry Weight of Shoots and Roots of Trees Grafted with "Rhode Red Valencia"}

At 3 months after grafting, the trees were harvested for dry weight. The division of the root and shoot was made at the top of the substrate. The dry weight of shoot and root were taken separately. The samples were dried in an oven (Oven PKN810, Yamato) at $70{ }^{\circ} \mathrm{C}$ for $144 \mathrm{~h}$ (6 days).

\subsection{Experimental Design and Statistical Analysis}

The design of the experiment was a randomized complete block with four blocks of six replicate trees of each treatment. The data was statistically analyzed using ANOVA and Fisher's least significant difference (LSD) with a $P<0.05$.

\section{Results and Discussion}

\subsection{Evaluation of Rootstock}

\subsubsection{Height and Diameter}

Rootstock height significantly differed $(P<0.05)$ in the interactions of rootstocks with substrate and substrate with fertilizer. In the interaction of rootstock with substrate (Table 2), the combination of Carrizo with coffee compost was the tallest, with a mean of $66.7 \mathrm{~cm}$. The substrate where rootstocks presented significantly smaller mean height was the mix that contained rice husk. For Swingle, the control, coco peat and compost substrates presented the tallest rootstock, with no significant difference among them (Table 2). Overall, the least favorable treatment was the Swingle with rice husk mix, with a mean of $31.3 \mathrm{~cm}$ (Table 2). Therefore, for both Carrizo and Swingle, the use of rice husk is not recommended. This data represents a possible savings for the grower by reducing the amount of commercial mix for coffee compost with Carrizo rootstock, with a significant increase of height. Also, more media substitutes can be used for Swingle, meaning more alternatives for the grower.

Table 2. Rootstock height, diameter and leaf chlorophyll as affected by rootstock (R), substrate (S) and fertilizer (F) interactions.

\begin{tabular}{clccc}
\hline Interactions & Height $(\mathbf{c m})^{\mathbf{1}}$ & $\begin{array}{c}\text { Diameter } \\
(\mathbf{m m})\end{array}$ & Chlorophyll \\
\hline $\mathrm{R} * \mathrm{~S}$ & & & \\
\hline Swingle & Control & $49.0 \mathrm{bc}^{2}$ & 4.25 & $61.8 \mathrm{abcd}$ \\
& Coco peat & $41.4 \mathrm{~cd}$ & 3.68 & $58.7 \mathrm{~cd}$ \\
& Compost & $43.0 \mathrm{~cd}$ & 4.18 & $62.2 \mathrm{abcd}$ \\
& Rice & $31.3 \mathrm{e}$ & 3.07 & $60.2 \mathrm{bcd}$ \\
\hline Carrizo & Control & $47.0 \mathrm{~cd}$ & 3.28 & $66.6 \mathrm{ab}$ \\
& Coco peat & $56.0 \mathrm{~b}$ & 3.58 & $64.3 \mathrm{abc}$ \\
& Compost & $66.7 \mathrm{a}$ & 4.00 & $55.6 \mathrm{~d}$ \\
& Rice & $40.3 \mathrm{c}$ & 2.66 & $69.1 \mathrm{a}$ \\
\hline $\mathrm{R} * \mathrm{~F}$ & & & \\
\hline Swingle & F1 & 39.78 & 3.77 & $57.8 \mathrm{a}$ \\
& F2 & 42.53 & 3.82 & $63.6 \mathrm{~b}$ \\
\hline Carrizo & $\mathrm{F} 1$ & 47.89 & 3.14 & $66.0 \mathrm{~b}$ \\
& F2 & 57.03 & 3.61 & $61.8 \mathrm{ab}$ \\
\hline
\end{tabular}


Table 2. Cont.

\begin{tabular}{clccc}
\hline Interactions & & Height $(\mathbf{c m})^{\mathbf{1}}$ & $\begin{array}{c}\text { Diameter } \\
(\mathbf{m m})\end{array}$ & Chlorophyll \\
\hline F* & & & & \\
\hline F1 & Control & $45.3 \mathrm{~b}$ & 3.65 & 71.2 \\
& Coco peat & $46.4 \mathrm{~b}$ & 3.64 & 68.8 \\
& Compost & $56.7 \mathrm{a}$ & 4.05 & 52.4 \\
& Rice & $26.9 \mathrm{c}$ & 2.49 & 71.4 \\
\hline F2 & Control & $50.6 \mathrm{ab}$ & 3.89 & 62.1 \\
& Coco peat & $50.9 \mathrm{ab}$ & 3.62 & 59.7 \\
& Compost & $52.9 \mathrm{ab}$ & 4.13 & 58.7 \\
& Rice & $44.7 \mathrm{~b}$ & 3.24 & 66.8 \\
\hline
\end{tabular}

${ }^{1}$ Final height and diameter minus initial height and diameter. ${ }^{2}$ Means followed by the same letter within interaction set are not significantly different $(P<0.05)$ by Fisher's least significant difference. Means with absence of letter $=\mathrm{F}$ test not significant $(P<0.05)$.

In the interaction of substrate and quantity of fertilizer, the least effective treatment for the growth of the citrus rootstocks producing the smallest trees was the combination of $5.6 \mathrm{~g}$ of fertilizer with rice husk media (Table 2). For any of the other substrate mixtures (control, coco peat and rice husk), a high application of fertilizer did not result in more development of the citrus rootstock. This can translate to economic savings and less labor.

As for diameter, no significant difference $(P<0.05)$ in any triple or double interaction was found (Table 2). However, main effects showed significant differences $(P<0.05)$ (Table 3$)$. The rootstock with the largest diameter was Swingle with a $3.80 \mathrm{~mm}$ diameter. Between fertilizers, the higher quantity of fertilizer presented a larger diameter mean of $3.72 \mathrm{~mm}$. Also, among the substrates, the larger diameters were found with control and coffee compost substrates-with means of $3.77 \mathrm{~mm}$ and $4.09 \mathrm{~mm}$, respectively-though they did not differ.

As in this experiment, the lowest diameter and height of shoots of tamarind (Dialium guineense Willd) were found with treatments of distinct proportions of river sand and rice husk (1:1, 1:2, 2:5 and 5:2) [33]. This suggests that rice husk may interfere with the growth of tamarind, as well as citrus as our data shows.

Table 3. Main effects on tree diameter.

\begin{tabular}{cc}
\hline Variables & Diameter $(\mathbf{m m})$ \\
\hline Rootstock $(\mathrm{R})$ & \\
\hline Swingle & $3.80 \mathrm{a}^{1}$ \\
Carrizo & $3.38 \mathrm{~b}$ \\
\hline Substrate (S) & \\
\hline Rice & $2.86 \mathrm{c}$ \\
Control & $3.77 \mathrm{ab}$ \\
Coco peat & $3.63 \mathrm{~b}$ \\
Compost & $4.09 \mathrm{a}$ \\
\hline Fertilizer (F) & \\
\hline F1 & $3.46 \mathrm{~b}$ \\
F2 & $3.72 \mathrm{a}$ \\
\hline
\end{tabular}

${ }^{1}$ Means followed with the same letter are not significantly different $(P<0.05)$ in accordance with the Fisher's least significant difference.

The most common techniques of grafting used with citrus rootstocks are T-budding and lateral budding, which can be performed effectively when the diameter of the rootstocks reaches 10-20 mm [34]. For this reason, even though Swingle with a mean of $4.09 \mathrm{~mm}$ (Table 3) presented a better diameter than Carrizo, we cannot deduce that the time needed for grafting was shortened.

In contrast to these results, in another study, rough lemon presented greater height and diameter in a substrate of sand and peat moss [35]. In another study, it was observed that rough lemon grown in 
a substrate composed of farmyard manure, soil, coco peat and compost (1:2:1) exhibited a higher mean diameter in comparison to other treatments [36]. The addition of compost to the growing media seems to positively impact the height and diameter of citrus varieties.

\subsubsection{Chlorophyll}

A significant difference $(P<0.05)$ was found for chlorophyll in the interactions of substrate with rootstock and of rootstock with quantity of fertilizer (Table 2). For rootstock and substrate, Carrizo showed the highest mean chlorophyll value, 69.1, in the media with $33 \%$ rice husk. This was significantly greater than Carrizo with coffee compost, Swingle with rice husk and Swingle with coco peat. Secondly, for the interaction of rootstock and fertilizer, the quantity of fertilizer did not have a significant effect on the chlorophyll content of Carrizo leaves. On the other hand, for Swingle, an application of $8.5 \mathrm{~g}$ of $18-6-12$ per pot was the best treatment for this parameter.

It should be mentioned that, during the experiment, the rootstocks had an incidence of mites. These were concentrated on the newest leaves of the tallest plants, which coincided with the rootstocks on coco peat, control and coffee compost substrate treatments. When mites eat, they change the surface of the leaves, which might have a negative effect on the chlorophyll reading and it might be possible that the damage done to the leaves by the mites affected the level of chlorophyll of these two rootstocks on all of the substrate treatments mentioned.

\subsection{Evaluation of Rootstocks Grafted with "Rhode Red Valencia"}

\subsubsection{Height}

Growth of the scion varied between substrates. The substrate with 33\% of rice husk resulted in the least favorable media for "Rhode Red Valencia" on both rootstocks (Table 2). Among the other substrate treatments, there was no significant difference $(P<0.05)$ on the growth of the scion. The only interaction that showed any significant difference or direct effect was the fertilizer by rootstock interaction. The lowest mean was observed with Swingle with $5.6 \mathrm{~g}$ of fertilizer (Table 4). On the other hand, for Carrizo, there was no significant difference between fertilizer treatments. Similar to this research, in a study, it was found that in the first year after budding, "Rhode Red Valencia" developed similarly when grafted on Carrizo and Swingle [37]. This data shows that the limited growth on the rootstocks before grafting did not continue limiting the growth of the scion when rice husk was used in the media.

Table 4. Interactions of rootstock (R) with fertilizer (F) and with substrate (S) on height, root and shoot dry weights, and chlorophyll of grafted trees.

\begin{tabular}{cccccc}
\hline Interactions & & Height $(\mathbf{c m})$ & Root Dry Weight (g) & Shoot Dry Weight (g) & Chlorophyll \\
\hline $\mathrm{R}{ }^{*} \mathrm{~F}$ & & & & \\
\hline Carrizo & $\mathrm{F} 1{ }^{1}$ & $24.1 \mathrm{a}^{2}$ & 6.47 & 7.45 & $66.0 \mathrm{a}$ \\
& $\mathrm{F} 2$ & $24.9 \mathrm{a}$ & 7.09 & 8.98 & $61.8 \mathrm{ab}$ \\
Swingle & $\mathrm{F} 1$ & $14.7 \mathrm{~b}$ & 6.47 & 7.53 & $57.8 \mathrm{~b}$ \\
& $\mathrm{~F} 2$ & $23.2 \mathrm{a}$ & 6.94 & & $63.6 \mathrm{a}$ \\
\hline $\mathrm{R} * \mathrm{~S}$ & & & 8.73 & $61.8 \mathrm{abcd}$ \\
\hline Swingle & Control & 23 & $7.79 \mathrm{bc} \mathrm{bc}$ & $58.7 \mathrm{~cd}$ \\
& Coco peat & 19.81 & $6.95 \mathrm{~cd}$ & $9.11 \mathrm{~b}$ & $62.2 \mathrm{abcd}$ \\
& Compost & 20.19 & $7.31 \mathrm{c}$ & $6.46 \mathrm{bc}$ & $66.6 \mathrm{bcd}$ \\
Carrizo & Rice husk & 12.69 & $5.49 \mathrm{~d}$ & $6.29 \mathrm{c}$ & $64.3 \mathrm{abc}$ \\
& Control & 24.50 & $5.82 \mathrm{~cd}$ & $8.4 \mathrm{bc}$ & $55.6 \mathrm{~d}$ \\
& Coco peat & 25.25 & $6.56 \mathrm{bcd}$ & $11.5 \mathrm{a}$ & $69.1 \mathrm{a}$ \\
\hline
\end{tabular}

${ }^{1} \mathrm{~F} 1=5.6 \mathrm{~g} ; \mathrm{F} 2=8.5 \mathrm{~g} .{ }^{2}$ Means followed by the same letter are not significantly different $(P<0.05)$ in accordance with the Fisher's least significant difference. Means with absence of letter or NS means that the F test was not significant $(P<0.05)$. 


\subsubsection{Chlorophyll}

Despite the pattern, on the other parameters, rootstocks grown in substrates with $33 \%$ rice husk exhibited high values of chlorophyll. In the case of Carrizo specifically, it was the treatment most favorable for leaf chlorophyll content (Table 4). The mite problem noted above may have impacted these results. This infestation occurred on all trees in all substrate treatments, except those with a third of rice husks. There was no incidence of mites from when the rootstock was grafted to the end of the experiment.

In terms of fertilizer, for each substrate, when comparing both quantities of fertilizers, a higher concentration of chlorophyll was present with a higher quantity $(8.5 \mathrm{~g})$ of fertilizer (Table 4$)$.

\subsection{3. $\mathrm{pH}$ and $\mathrm{EC}$}

In both pour-through results and the analysis of the Central Analytical Laboratory of the University of Puerto Rico (Table 5), the substrates demonstrated a higher (more basic) pH (Tables 5 and 6) than is preferred for optimal citrus growth. An ideal $\mathrm{pH}$ for a good citrus development should be between 5.5 and $6.0[23,38]$.

An optimal electric conductivity of the substrates should range from 0.20 to $1.0 \mathrm{dS} / \mathrm{m}$. The sensitivity of the plant to the electric conductivity of the substrates will depend on the crop [17]. The results from the Central Analytical Laboratory of the University of Puerto Rico (Table 5) showed that only the compost had an optimal EC. The EC results were $0.0494 \mathrm{dS} / \mathrm{m}$ for the control, $0.0711 \mathrm{dS} / \mathrm{m}$ for coco peat, $0.433 \mathrm{dS} / \mathrm{m}$ for compost, and $0.0666 \mathrm{dS} / \mathrm{m}$ for rice husk (Table 5). The EC results were mostly within the ideal range for the first 3 months of the study (Table 7). After 3 months, there was a second fertilizer application that increased the EC values above what is optimal for citrus. The difference in the values across months could have been affected by the water source for irrigation used in the greenhouse, which was river water (Table 5).

Table 5. Report of chemical properties of substrates of Central Analytical Laboratory at EAS, Río Piedras.

\begin{tabular}{|c|c|c|c|c|c|c|}
\hline & & Control & Coco Peat & Compost & Rice Husk & Water \\
\hline $\mathrm{pH}$ & & 7.79 & 7.34 & 7.06 & 7.56 & 7.5 \\
\hline $\mathrm{EC}$ & $\mathrm{dS} / \mathrm{m}$ & 0.0494 & 0.0711 & 0.433 & 0.0666 & 0.12 \\
\hline
\end{tabular}


Table 6. $\mathrm{pH}$ measurements of all substrates and quantities of fertilizer treatments by month.

\begin{tabular}{|c|c|c|c|c|c|c|c|c|c|c|c|}
\hline & April 2015 & May 2015 & June 2015 & July 2015 & August 2015 & September 2015 & October2015 & November 2015 & December 2015 & January 2016 & February 2016 \\
\hline CONTROL + F1 & 7.4 & 7.4 & 7.5 & 7.4 & 7.4 & 7.2 & 7.1 & 7.0 & 7.1 & 7.1 & 7.0 \\
\hline CONTROL + F2 & 7.4 & 7.3 & 7.2 & 7.4 & 7.1 & 7.0 & 7.0 & 6.9 & 6.9 & 6.8 & 7.0 \\
\hline COCO PEAT + F1 & 7.3 & 7.3 & 7.2 & 7.2 & 7.3 & 6.9 & 7.2 & 7.1 & 7.2 & 7.3 & 7.1 \\
\hline COCO PEAT + F2 & 7.3 & 7.0 & 7.0 & 7.2 & 6.8 & 6.6 & 6.7 & 6.3 & 6.4 & 6.5 & 6.8 \\
\hline COMPOST + F1 & 7.5 & 7.5 & 7.2 & 7.4 & 7.3 & 6.6 & 7.0 & 6.9 & 7.0 & 7.0 & 7.0 \\
\hline COMPOST + F2 & 7.6 & 7.5 & 7.2 & 7.2 & 7.3 & 6.7 & 7.2 & 7.1 & 7.1 & 7.2 & 7.1 \\
\hline RICE HUSK + F1 & 7.5 & 7.6 & 7.3 & 7.4 & 7.4 & 6.8 & 7.1 & 6.9 & 6.9 & 6.9 & 7.2 \\
\hline RICE HUSK + F2 & 7.5 & 7.4 & 7.1 & 7.1 & 7.2 & 7.0 & 6.7 & 6.8 & 6.7 & 6.5 & 6.9 \\
\hline
\end{tabular}

Table 7. Electric conductivity measurements $(\mathrm{dS} / \mathrm{m})$ of all substrates and quantities of fertilizer treatments by month.

\begin{tabular}{|c|c|c|c|c|c|c|c|c|c|c|c|}
\hline & April 2015 & May 2015 & June 2015 & July 2015 & August 2015 & September 2015 & October 2015 & November 2015 & December 2015 & January 2016 & February 2016 \\
\hline CONTROL + F1 & 1.02 & 1.4 & 0.8 & 0.72 & 1.58 & 2.03 & 1.58 & 2.29 & 1.89 & 1.49 & 1.66 \\
\hline CONTROL + F2 & 1.06 & 1.52 & 1.67 & 1.45 & 2.93 & 2.98 & 2.3 & 2.38 & 2.81 & 3.24 & 1.33 \\
\hline COCO PEAT + F1 & 0.81 & 0.61 & 0.77 & 1.2 & 0.8 & 1.71 & 1.6 & 1.81 & 1.79 & 1.75 & 1.42 \\
\hline COCO PEAT + F2 & 1.13 & 1.41 & 0.99 & 1.4 & 2.5 & 2.81 & 2.2 & 4.75 & 3.61 & 2.48 & 1.91 \\
\hline COMPOST + F1 & 2.04 & 1.33 & 0.79 & 1.91 & 2.7 & 3.83 & 3.2 & 1.16 & 2.75 & 4.35 & 2.07 \\
\hline COMPOST + F2 & 1.34 & 2.35 & 0.98 & 2.66 & 2.92 & 3.27 & 1.78 & 3.13 & 2.56 & 2.0 & 1.55 \\
\hline RICE HUSK + F1 & 0.57 & 0.63 & 1.03 & 0.58 & 1.05 & 1.97 & 1.65 & 1.43 & 1.87 & 2.3 & 0.98 \\
\hline RICE HUSK + F2 & 0.93 & 0.9 & 2.87 & 1.3 & 1.45 & 2.45 & 1.96 & 2.1 & 2.33 & 2.55 & 1.37 \\
\hline
\end{tabular}




\subsubsection{Dry Weight of Shoots and Roots of Trees Grafted with "Rhode Red Valencia"}

For both root and shoot dry weight, the quantity of fertilizer (as an individual variable) had no significant effect $(P>0.05)$ (Table 4$)$, which indicates that we can obtain similar growth with either fertilizer treatment. This represents an economic savings in terms of fertilizer expenses and application if the lower rate is used. The only significant interaction was that of rootstock and substrate (Table 4). At the first phase of the experiment (Tables 2 and 3), the amount of fertilizer used influenced growth of the rootstock. However, as time passed, the early effects did not persist. In the end, there were similar results in the growth of citrus rootstocks in either of the fertilizer treatments for these substrates mixtures and proportions of its components. Observing the data by rootstock, for Carrizo, the best substrate for shoot and root mass was that with 1/3 coffee compost (Table 4). Carrizo also presented higher root and shoot dry weight than Swingle in the substrate with coffee compost (Table 4).

For Swingle, the lowest value of both shoot and root mass was found with $1 / 3$ rice husk (Table 4 ). In another study, the effect of different proportions of perlite and rice husk partially boiled with peat moss and grown in different proportions $(10 \%, 15 \%, 25 \%, 30 \%$ and $35 \%)$ on tomato plants resulted in higher root dry weight in comparison with the other treatments [39]. Parboiled fresh rice hull (PFH) is rice that has been partially boiled while still in the husk [39]. For this type of crop (tomato), incorporating rice husk can be positive for the development of the plant. For citrus, as observed in this study, incorporation of rice husk in the substrate had a detrimental effect on rootstock growth.

\section{Conclusions}

Our results indicated that rice husk without any other treatment should not be incorporated in a substrate mix for the citrus rootstocks used in this experiment. For Carrizo, it is recommended to use coffee compost in the substrate, as it showed increased growth. For Swingle, any of the other substrates (compost, control and coco peat) can be used for production of this rootstock with good development of the plant. The results of different treatments of quantities of fertilizers showed similar results without showing a significant difference between them. This suggests that it is not necessary to apply a higher quantity of fertilizer to achieve a greater development of the rootstock. This experiment demonstrated that other media components can be used for the production of citrus liners without affecting tree growth. For further research, the amounts of compost and coco peat should be increased, as alternatives to the expensive commercial mix.

Author Contributions: D.R. conceived and designed the experiments, contributed with materials and analysis tools and reviewed the final manuscript; S.A. performed the experiments and analyzed the data and wrote the manuscript draft.

Funding: This research was sponsored by the National Institute of Food and Agriculture. The funding source was the Hatch Project (No. PR00451) Production of healthy citrus plants in Puerto Rico at the University of Puerto Rico at Mayagüez.

Conflicts of Interest: The authors declare no conflict of interest.

\section{References}

1. Ingreso Bruto Agrícola; Departamento de Agricultura, División Estadísticas Agrícolas, Estado Libre Asociado de Puerto Rico: San Juan, PR, USA, 2015.

2. Chung, K.R.; Brlansky, R.H. Citrus Diseases Exotic to Florida: Huanglongbing (citrus greening). In Plant Pathology Department Fact Sheet PP-210, Florida Cooperative Extension Service, Institute of Food and Agricultural Sciences, University of Florida; University of Florida: Gainesville, FL, USA, 2005.

3. Batool, A.; Iftikhar, Y.; Mughal, S.M.; Khan, M.M.; Jaskani, M.J.; Abbas, M.; Khan, I.A. Citrus Greening Disease-A major cause of citrus decline in the world-A Review. Hort. Sci. 2007, 34, 159-166. [CrossRef]

4. Halbert, S.E.; Núñez, C.A. Distribution of the Asian citrus psyllid, Diaphorina citri Kuwayama (Rhynchota: Psyllidae) in the Caribbean basin. Fla. Entomol. 2004, 87, 401-402. [CrossRef]

5. Alvarado Ortíz, A.N.; Estévez de Jensen, C.; Abreu, E.; Román, F.; Almodóvar, W. “Citrus greening” en Puerto Rico: Muestreo preliminar. Soc. Puertorriquena Cienc. Agricolas. Mem. Reun. Anu. 2010, 11, 32. 
6. Flores Ortega, C. Secretary of the Department of Agriculture. Agricultura Busca Eliminar Amenaza Para Cítricos. La Perla del sur, Newspaper. 2017. Available online: http:/ / www.periodicolaperla.com/agriculturabusca-eliminar-amenaza-citricos / (accessed on 8 June 2015).

7. Pluke, R.W.; Qureshi, J.A.; Stansly, P.A. Citrus flushing patterns, Diaphorina citri (Hemiptera: Psyllidae) populations and parasitism by Tamarixia radiata (Hymenoptera: Eulophidae) in Puerto Rico. Fla. Entomol. 2008, 91, 36-42. [CrossRef]

8. Tiwari, S.; Mann, R.S.; Rogers, M.E.; Stelinski, L.L. Insecticide resistance in field populations of Asian citrus psyllid in Florida. Pest. Manag. Sci. 2011, 67, 1258-1268. [CrossRef] [PubMed]

9. Hoffman, M.T.; Doud, M.S.; Williams, L.; Zhang, M.Q.; Ding, F.; Stover, E.; Duan, Y.P. Heat treatment eliminates' Candidatus Liberibacter asiaticus' from infected citrus trees under controlled conditions. Phytopathology 2013, 103, 15-22. [CrossRef] [PubMed]

10. Hodges, A.W.; Spreen, T.H. Economic Impacts of Citrus Greening (HLB) in Florida; University of Florida: Gainesville, FL, USA, 2006.

11. Davies, F.S.; Zalman, G. Fertilization and growth of field-grown citrus nursery trees in Florida. HortTechnology 2008, 18, 29-33.

12. Castle, W.S. Root system development in field-and container-grown young citrus trees. Proc. Fla. State Hort. Soc. 1987, 90, 70-74.

13. Albrecht, U.; McCollum, G.; Bowman, K.D. Influence of rootstock variety on Huanglongbing disease development in field-grown sweet orange. (Citrus sinensis L. Osbeck) trees. Sci. Hortic. 2012, 138, 210-220. [CrossRef]

14. Román, F.; González, A. Crecimiento, rendimiento y calidad de fruta de la china 'Washington Navel' en cuatro patrones durante los primeros cuatro años de producción. J. Agric. Univ. P. R. 2001, 85, 143-149.

15. Avilan, L.; Rengifo, C. Los Cítricos, 1st ed.; Editorial América C. A.: Venezuela, 1987.

16. Hutchison, D.J. Swingle citrumelo-a promising rootstock hybrid. Proc. Fla. State Hort. Soc. 1974, 87, 89-91.

17. Mateus, D.; Ordúz, J. Generalidades de Los Cítricos y Recomendaciones Agronómicas Para su Cultivo en Colombia; Corporación Universitaria Lasallista: Antioquia, Colombia, 2012.

18. Toplu, C.; Kaplankiran, M.; Demirkeser, T.H.; Yildiz, E. The effects of citrus rootstocks on Valencia Late and Rhode Red Valencia oranges for some plant nutrient elements. Afr. J. Biotechnol. 2008, 7, 4441-4445.

19. Huallparimachi Suárez, M.; Negrón Pérez, E.; Román Pérez, F.M.; González Vélez, A. Utilización de Parámetros de Calidad de Jugo Para Determinar Tiempo Óptimo de Cosecha en Variedades de Naranjas 'Hamlin' y 'Rhode Red Valencia'. Master's Thesis, Universidad de Puerto Rico, Recinto Universitario de Mayagüez, Mayagüez, Puerto Rico, 2009. Available online: https:/ /wordpress.uprm.edu/oeg/es/tesisdigitales-de-ciencias-y-tecnologia-de-alimentos/\#2009 (accessed on 3 March 2015).

20. Briceño, J.; Gudiño, J.; Zorrilla, E. Sustrato a base de café, estiércol, coco y arena para la germinación de semillas de tomate (Lycopersicum esculentum). Creando 2008, VI-VIII, 81-85.

21. Olivo, V.B.; Buduba, C.G. Influencia de seis sustratos en el crecimiento de Pinus ponderosa producido en contenedores bajo condiciones de invernáculo. Bosque 2006, 27, 267-271. [CrossRef]

22. Pire, R.; Pereira, A. Propiedades físicas de componentes de sustratos de uso común en la horticultura del estado Lara, Venezuela. Propuesta metodológica. Bioagro 2003, 15, 55-63.

23. Molina, E. Nutrición y fertilización de la naranja. Inf. Agron. 2000, 40, 5-13.

24. Abad, M.; Noguera, P.; Puchades, R.; Maquieira, A.; Noguera, V. Physico-chemical and chemical properties of some coconut coir dusts for use as a peat substitute for containerized ornamental plants. Bioresour. Technol. 2002, 82, 241-245. [CrossRef]

25. Berjón, M.A.; Murra, P.N.; García, V.N.; Pérez, M.L.S. Los sustratos para el semillero hortícola. Compendios de Horticultura 1999, 13, 58-59.

26. Cabrera, R.I. Propiedades, uso y manejo de sustratos de cultivo para la producción de plantas en maceta. Rev. Chapingo Ser. Hortic. 1999, 5, 5-11. [CrossRef]

27. Evans, M.R.; Konduru, S.; Stamps, R.H. Source variation in physical and chemical properties of coconut coir dust. HortScience 1996, 31, 965-967.

28. Escobar, N.E.; Delgado, J.M.; Jola, N.R. Respuesta agronómica de Zea mays L. y Phaseolus vulgaris L. a la fertilización con compost. Rev. Luna. Azul 2013, 37, 18-29.

29. García, O.; Alcántar, G.; Cabrera, R.; Gavi, F.; Volke, V. Evaluación de sustratos para la producción de Epipremnum aureum y Spathiphyllum wallisii cultivadas en maceta. Terra 2001, 19, 249-258. 
30. Tsakaldimi, M. Kenaf (Hibiscus cannabinus L.) core and rice hulls as components of container media for growing Pinus halepensis M. seedlings. Bioresour. Technol. 2006, 97, 1631-1639. [CrossRef] [PubMed]

31. Chong, J.A.; Dumas, J.A. Coffee pulp compost: Chemical properties and distribution of humic substances. J. Agric. Univ. P. R. 2012, 96, 77-87.

32. Ruter, J.M.; Garber, M.P. Measuring Soluble Salts and $p H$ with the Pour-Through Method; University of Georgia Ornamental Horticulture Facts H-93-015; Bugwood: Tifton, GA, USA, 1993.

33. Osaigbovo, A.U.; Nwaoguala, C.N.C. Growth response of black velvet tamarind (Dialium guineense Willd) seedling to different potting media. J. Appl. Nat. Sci. 2011, 3, 166-170. [CrossRef]

34. Killmann, W.W.; Shaari, W.C.; Kikuchi, S.; Martin, F.W.; L Ruberté, R.M.; Mora, R. Aspectos Técnicos Sobre Cuarenta y Cinco Cultivos Agrícolas de Costa Rica; Ministerio de Agricultura y Ganadería: San José, CA, USA, 1991.

35. Khan, M.M.; Khan, M.A.; Abbas, M.; Jaskani, M.J.; Ali, M.A.; Abbas, H. Evaluation of potting media for the production of rough lemon nursery stock. Pak. J. Bot. 2006, 38, 623.

36. Bhagat, S.; Thakur, A.; Dhaliwal, H.S. Organic amendments influence growth, buddability and budding success in rough lemon (Citrus jambhiri Lush.). Biol. Agric. Hortic. 2013, 29, 46-57. [CrossRef]

37. Davies, F.S.; Zalman, G.R. Nitrogen, rootstocks, and growth of young 'Rhode Red' Valencia orange trees. HortScience 2001, 36, 62-65.

38. Morton, J.F. Fruits of Warm Climates; CABI: Wallingford, UK, 1987.

39. Evans, M.R.; Gachukia, M. Fresh parboiled rice hulls serve as an alternative to perlite in greenhouse crop substrates. HortScience 2004, 39, 232-235.

(C) 2018 by the authors. Licensee MDPI, Basel, Switzerland. This article is an open access article distributed under the terms and conditions of the Creative Commons Attribution (CC BY) license (http:/ / creativecommons.org/licenses/by/4.0/). 